\title{
Assessment of the Seed Vigour Potential in Different Varieties of Wheat
}

\author{
Vikash Kumar $^{1 *}$, R.C. Poonia ${ }^{2}$ and Kautilya Chaudhary ${ }^{3}$ \\ ${ }^{1}$ Seed Science and Technology Section, Department of GPB, ${ }^{2}$ Directorate of Farms, CCS \\ HAU, Hisar, India \\ ${ }^{3}$ Department of Soil Science and Agriculture Chemistry, \\ CSAUA\&T, Kanpur, India \\ *Corresponding author
}

\section{A B S T R A C T}

\begin{tabular}{|l|}
\hline Ke y w o r d s \\
Seed Vigour \\
Potential \\
Wheat, Vigour \\
parameter
\end{tabular}

The current study was conducted at Chaudhary Charan Singh Haryana Agricultural University, Hisar to assess the seed vigour potential of 28 wheat varieties. These varieties assessed under 13 different parameter of vigour viz. Test weight (g), Standard germination $(\%)$,Seedling length $(\mathrm{cm})$, Seedling dry weight $(\mathrm{g})$, Vigour index-I $[\mathrm{SG}(\%) \times \mathrm{SL}(\mathrm{cm})]$, Vigour index-II $[\mathrm{SG}(\%) \times \mathrm{SDW}(\mathrm{g})]$, Accelerated ageing $(\%)$, Electrical conductivity $(\mu \mathrm{s} / \mathrm{cm} / \mathrm{seed})$, Tetrazolium test $(\%), \mathrm{pH}$ Exudates test, Seedling emergence index, Mean emergence Time and Seedling establishment (\%). For these parameters 28 varieties show significant variation, this variation among vigour parameters of different varieties is closely associated with genetic makeup of these varieties due which some are superior while some are inferior. Varieties like C 306, PBW 590 and PBW 373 showed poor performance for all most all viability and vigour parameters whereas, variety DPW 71 showed very good performance for vigour parameters while it showed average performance for viability parameters.

\section{Introduction}

Wheat botanically is a grass which is cultivated for its seed that is cereal grain. Wheat is a staple food all over the world. There are numerous species of wheat which together makes the genus Triticum out of which most widely cultivated is common wheat (Triticum aestivum).

Among all the food crops, cultivated area of wheat is highest (220.4 million hectares, FAO STAT.2014), in 2016 world production of wheat was 749 million tones, making it the second most-produced cereal after maize (FAO 2016).
Quality of seed directly effects the yield of wheat crop. use of low quality seeds leads to delay of emergence of seedlings in the field, which results in smaller growth of the aerial plant parts as well as smaller growth of the root system (MEROTTO-JÚNIOR, 1999) low and irregular plant stand in the field (TEKRONY et al., 1991); and lower tolerance to drought (SLOANE et al., 2004; LIAO et al., 2006). These factors may result in grain yield far behind the expected.

The advantages of high seed vigour are most apparent in early seedling growth and are often associated with rapid and high rate of 
emergence and crop stand establishment. Seed which perform well in some or all of these aspects is termed high-vigour seed (Black and Bewely, 2000). Vigour is the first component of seed quality, loss of which is followed by loss of germination capacity and viability (Trawatha et al., 1995). Now a days, the seed vigour as a quality attribute has gained significance which is a highly complex character influenced by many parameters.

The establishment of good plant stand is one of the requirements for higher production. It was found that plants from higher quality seed produces $18 \%$ higher yield than those obtained from low quality seed (Bishnoi and Delouche 1980).

\section{Materials and Methods}

28 varieties of wheat $(\mathrm{WH} 542, \mathrm{WH} 711, \mathrm{WH}$ 730, WH 1021, WH 1025, WH 1063,WH 1080, WH 1081, WH 1105, WH 1124, WH 1138, PBW 343, PBW 373, PBW 509, PBW 550, PBW 590, HD 2733, HD 2851, HD 2932, HD 2967, HD 3043, DBW 17, DBW 71, DPW 621-50, KRL 19, C 306, K 307, RAJ 3765) were collected from wheat and barley section, department of genetics and plant breeding, CCS HAU, Hisar and research were conducted under fallowing parameters

\section{Laboratory parameters}

The study was conducted in the laboratory of Seed Science and Technology section.

Department of Genetics and Plant Breeding and following observations were recorded.

\section{Test weight (g)}

One thousand seeds in three replications and from each variety/genotype were counted and weighed and average seed weight of each variety was calculated and expressed in gram.

\section{Standard germination}

Germination test was conducted by "Between paper method" as per guidelines of ISTA (Anonymous, 2011). Hundred seeds were counted in three replications and kept over moist towel tissue paper in liner fashion. They were wrapped over by wax paper and kept into the germination chamber at $20 \pm 10 \mathrm{C}$ temperature and $90 \pm 2$ per cent relative humidity. At the end of 7 th day of germination test, the number of normal, abnormal and dead seedlings in each replication was counted and only normal seedlings were considered as germination and expressed in percentage.

\section{Seedling length (cm.)}

Ten normal seedlings were randomly selected from the each replication of all the varieties/genotypes and their length was measured in $\mathrm{cm}$. Average length of these seedlings were calculated.

\section{Seedling dry weight (mg)}

Ten normal seedlings which were used for the measurement of seedling length were also used for seedling dry weight measurement. The selected seedlings were kept in butter paper and dried in hot air oven at $80 \pm 10 \mathrm{C}$ temperature for 24 hours. Then seedlings were removed from oven and allowed to cool in desiccator for 30 minutes before weighing on an electronic balance. The average weight of dried seedlings from each replication was calculated and expressed as dry weight of seedling in milligrams (Anonymous, 2011).

\section{Seedling vigour indices}

Seedling vigor indices were calculated by using the formula suggested by Abdul-Baki and Anderson (1973) and expressed as whole number. 
Seedling vigour index-I = Standard germination $(\%) \mathrm{x}$ seedling length $(\mathrm{cm})$

Seedling vigour index-II $=$ Standard germination $(\%)$ x seedling dry weight $(\mathrm{mg})$

\section{Accelerated Aging (AA) test}

Sufficient number of seeds were taken from each variety/genotype and kept over wire mess in a plastic box. In each box $40 \mathrm{ml}$ distilled water was poured and box were kept into accelerated aging chamber at $40 \pm 1{ }^{\circ} \mathrm{C}$ temperature and relative humidity $(\mathrm{RH})$ about $100 \%$ for 72 hours for aging. After aging, 100 seeds in three replications from each variety/genotype were taken and used further for standard germination evaluation according to rule of International Seed Testing Association (Anonymus, 2011). The number of normal seedlings were counted and expressed in percentage.

\section{Electrical conductivity of seed leachets $(\mathrm{mS} / \mathrm{cm} / \mathbf{5 0}$ seeds)}

Fifty seeds from each variety/genotype were counted into three replications and surface sterilized by using $0.1 \%$ mercuric chloride solution and then rinsed with distilled water three times. These seeds were soaked into $75 \mathrm{ml}$ distilled water for 24 hours at $25 \pm 10 \mathrm{C}$ temperature. After 24 hour soaking seed was separated from the water and electrical conductivity of seed leachets was measured using the Digital Conductivity Meter and expressed in decimals per centimeter (dS/cm1/50 seeds) (Presley, 1958).

\section{Tetrazolium test $(\%)$}

Tetrazolium test was conducted according to procedure suggested by Moore (1973). Fifty seeds from each variety/genotype were counted into three replications and soaked into $50 \mathrm{ml}$ of distilled water for 16 hours at $25 \pm$ 10C temperature. After the pre-conditioning, soaked seeds were subjected to longitudinal cut as to embryo into two parts and the prepared seeds were stained in $0.5 \%$ Tetrazolium solution (2,3,5-triphenyl tetrazolium chloride) for $4 \mathrm{hr}$. at $30^{\circ} \mathrm{C}$ in petriplates. After staining seed was separated from solution and examined under magnified glass. Seed showing pink colouration considered as viable while unstained as non viable.

\section{pH exudates test}

This test is based on the principal of seed deterioration progress. During the aging process the cell wall become less rigid and contents of cell come out along with water during imbibition procedure resulting lower $\mathrm{pH}$ of solution. The $\mathrm{pH}$ exudates testes a colorimetric method that predicts the germinability of individual seed based on a colour change in the seed exudates from colorless to rosey colour. Three replications of 100 seeds were placed in 100 cells of plastic trays, 100 seeds per tray and one seed per cell and $2 \mathrm{ml}$ of distilled water was added to each cell. The seeds were then allowed to imbibe for 30 minutes at $25^{\circ} \mathrm{C}$. At the end of imbibition period $25 \mu \mathrm{l}$ of phenolphthalein solution and $50 \mu \mathrm{l}$ of sodium carbonate solution were added to soak water in each cell and the trays were agitated to promote mixing. Those cells sowing rosy colour were considered viable while cell without colour/pale colour as non viable. The total viable seeds were counted and expressed in numbers.

\section{Field parameters}

100 seeds of all 28 wheat varieties were sown in three replications of Randomize Block Design (RBD) on research farm of Seed Science and Technology, CCS HAU, Hisar during year 2013-2014 for recording the following field parameters: 


\section{Seedling emergence index}

Line sowing of 100 seeds of each variety in three replications was done in well prepared field. The number of seedling emerged were counted daily up to the seedling establishment. Seedling Emergence Index was calculated using formulae as suggested by Maguire (1962).

No. of seedlings emerged No. of seedlings emerged

Field Emergence Index $(\mathrm{FEI})=$

\section{Mean emergence time}

The mean emergence time (MET) was calculated for each treatment combination using the formula cited by Ellis and Roberts (1980).

$\mathrm{MET}=\Sigma \mathrm{nt} / \Sigma \mathrm{n}$

Where,

n- Number of seeds newly germinated at times' $\mathrm{t}$ '

$\mathrm{t}$ - Days from sowing

$\Sigma \mathrm{n}$ - Final emergence of seedlings

\section{Seedling establishment}

In field condition daily newly emerged seedling were counted till seedling emergence become constant and no further seedling emerged. The final day count of total number of seedling emerged was used for calculation of average number of seedling establishment.

\section{Statistical analysis}

The mean value of observations recorded on different parameters was subjected to statistical analysis. The factorials CRD (Completely Randomized Design) for laboratory parameters and RBD (Randomized Block Design) for field parameters were used for analysis of variance (Panse and Sukhatme, 1967).

\section{Results and Discussion}

Among all the seed quality attributes seed vigour is most important one. Vigour is the first component of seed quality, which is lost, followed by a loss of germination capacity and viability (Trawatha et al., 1995).

Decreased field emergence and uniformity is directly related with low seed vigour potential of a variety. Generally, the standard germination of a seed lot does not give the actual estimate of field performance. So, there is need to have some reliable parameters, for evaluation of the seed quality in wheat. In order to assess the seed quality of different varieties of wheat in terms of field performance, the seeds were subjected to number of physiological and biochemical tests which can be used reliably to predict crop establishment under the field conditions.

In the present study, different wheat varieties were evaluated with a view to have substantial information on their vigour parameters. The test weight of 1000 seeds of all the 28 wheat varieties was recorded and the maximum test weight was recorded for C- 306 (48.85g) whereas, lowest test weight was observed for KRL -19 (32.47 g). The varieties WH 1025 and WH 542 recorded maximum germination (92\%) followed by WH 711 and KRL 19 (91 $\%$ ), whereas the varieties PBW 373 and DBW 17 showed minimum germination (81\%) (Table 1 and 2). 
Table.1 Seed viability and vigor parameters of different variety of wheat

\begin{tabular}{|c|c|c|c|c|c|c|c|c|}
\hline S. No. & Varieties & SW (g) & \multicolumn{2}{|c|}{ SG (\%) } & $\mathrm{SL}(\mathrm{cm})$ & SDW (mg) & SVI-1 & SVI-2 \\
\hline 1 & WH 542 & 32.84 & 92.00 & (74) & 22.3 & 124 & 2052 & 11438 \\
\hline 2 & WH711 & 43.92 & 91.00 & (73) & 21.9 & 138 & 1993 & 12528 \\
\hline 3 & WH 730 & 42.22 & 92.00 & (74) & 22.2 & 147 & 2042 & 13494 \\
\hline 4 & WH1021 & 46.39 & 90.00 & (72) & 21.9 & 138 & 1971 & 12450 \\
\hline 5 & WH1025 & 39.31 & 92.00 & (74) & 21.2 & 157 & 1950 & 14414 \\
\hline 6 & WH1063 & 42.31 & 89.00 & (71) & 21.7 & 157 & 1931 & 13945 \\
\hline 7 & WH 1080 & 40.75 & 85.00 & (67) & 20.2 & 143 & 1717 & 12127 \\
\hline 8 & WH 1081 & 40.61 & 89.00 & (71) & 22.5 & 162 & 2003 & 14389 \\
\hline 9 & WH1105 & 40.65 & 87.00 & (70) & 20.9 & 138 & 1818 & 11977 \\
\hline 10 & WH1124 & 42.54 & 88.00 & (70) & 23.1 & 155 & 2033 & 13669 \\
\hline 11 & WH1138 & 41.9 & 85.00 & (67) & 22.9 & 143 & 1947 & 12155 \\
\hline 12 & PBW 343 & 39.71 & 89.00 & (71) & 23.7 & 123 & 2109 & 10918 \\
\hline 13 & PBW 373 & 37.53 & 81.00 & (64) & 20.9 & 131 & 1693 & 10638 \\
\hline 14 & PBW 509 & 39.66 & 90.00 & (72) & 24.1 & 122 & 2169 & 11010 \\
\hline 15 & PBW 550 & 40.07 & 90.00 & (72) & 25.1 & 169 & 2259 & 15240 \\
\hline 16 & PBW 590 & 39.88 & 80.00 & (63) & 19.2 & 103 & 1536 & 8214 \\
\hline 17 & HD 2733 & 47.52 & 89.00 & (71) & 23.0 & 165 & 2047 & 14714 \\
\hline 18 & HD 2851 & 45.47 & 85.00 & (67) & 22.2 & 152 & 1887 & 12948 \\
\hline 19 & HD 2932 & 44.86 & 90.00 & (72) & 23.8 & 157 & 2142 & 14100 \\
\hline 20 & HD 2967 & 41.8 & 85.00 & (67) & 22.7 & 157 & 1930 & 13317 \\
\hline 21 & HD 3043 & 39.9 & 84.00 & (66) & 23.7 & 146 & 1991 & 12264 \\
\hline 22 & DBW 17 & 39.65 & 81.00 & (64) & 20.3 & 137 & 1644 & 11124 \\
\hline 23 & RAJ 3765 & 39.57 & 90.00 & (72) & 22.9 & 148 & 2061 & 13350 \\
\hline 24 & DPW 621-50 & 41.47 & 85.00 & (67) & 21.9 & 158 & 1862 & 13458 \\
\hline 25 & KRL 19 & 32.47 & 91.00 & (73) & 19.9 & 120 & 1811 & 10890 \\
\hline 26 & C 306 & 48.85 & 83.00 & (66) & 25.3 & 133 & 2100 & 11012 \\
\hline 27 & K 307 & 43.81 & 89.00 & (71) & 24.0 & 168 & 2136 & 14952 \\
\hline 28 & DPW71 & 42.48 & 90.00 & (72) & 26.3 & 130 & 2367 & 11700 \\
\hline & Mean & 41.36 & 88. & & 22.6 & 144 & 1978 & 12538 \\
\hline & Range & $\begin{array}{c}32.47- \\
48.55\end{array}$ & $81-$ & & $\begin{array}{l}19.2- \\
26.3\end{array}$ & $\begin{array}{c}102.6- \\
169.3\end{array}$ & $\begin{array}{l}1537- \\
2371\end{array}$ & $\begin{array}{l}8216- \\
15245\end{array}$ \\
\hline & CD (at 5\%) & 0.01 & 4.1 & & 2.2 & 7 & 241 & 1018 \\
\hline
\end{tabular}

SW- Seed weight, SG- Seed germination, SL- Seedling length, SDW- Seedling dry weight, SV-I- Seedling vigour index-I, SV-2 
Table.2 Seed viability and vigor parameters of different variety of wheat

\begin{tabular}{|c|c|c|c|c|c|c|c|c|}
\hline S. No. & & $\mathbf{A A}$ & EC & TZ & PH & SEI & MET & SE \\
\hline & WH 542 & $56.78 \quad(48.66)$ & 0.33 & 95 & 96 & 8.22 & 8.84 & 70 \\
\hline 2 & WH711 & $57.11 \quad(48.85)$ & 0.34 & 92 & 98 & 8.62 & 8.68 & 72 \\
\hline 3 & WH 730 & $55.44 \quad(47.89)$ & 0.32 & 93 & 96 & 8.21 & 8.84 & 70 \\
\hline 4 & WH1021 & $(47.43)$ & 0.33 & 92 & 95 & 9.22 & 7.72 & 69 \\
\hline 5 & WH1025 & $56.11 \quad(48.28)$ & 0.32 & 93 & 96 & 9.94 & 7.35 & 70 \\
\hline 6 & WH1063 & $56.11 \quad(48.28)$ & 0.32 & 90 & 94 & 9.57 & 7.67 & 71 \\
\hline 7 & WH 1080 & $(45.04)$ & 0.37 & 87 & 90 & 8.48 & 7.14 & 63 \\
\hline 8 & WH 1081 & $52.84 \quad(46.41)$ & 0.36 & 90 & 89 & 8.41 & 7.93 & 64 \\
\hline 9 & WH1105 & $52.71 \quad(46.33)$ & 0.4 & 87 & 95 & 8.38 & 7.93 & 65 \\
\hline 10 & WH1124 & $50.44 \quad(45.04)$ & 0.44 & 88 & 98 & 8.28 & 7.76 & 63 \\
\hline 11 & WH1138 & $48.31 \quad(43.83)$ & 0.43 & 85 & 92 & 7.48 & 7.95 & 61 \\
\hline 12 & PBW 343 & $53.84 \quad(46.98)$ & 0.34 & 92 & 94 & 8.71 & 7.75 & 66 \\
\hline 13 & PBW 373 & $45.01 \quad(41.95)$ & 0.44 & 88 & 93 & 7.69 & 7.72 & 58 \\
\hline 14 & PBW 509 & $54.98 \quad(47.63)$ & 0.33 & 95 & 95 & 9.53 & 7.64 & 70 \\
\hline 15 & PBW 550 & $52.71 \quad(46.33)$ & 0.33 & 95 & 98 & 8.94 & 7.82 & 68 \\
\hline 16 & PBW 590 & $45.31 \quad(42.12)$ & 0.45 & 85 & 85 & 8.82 & 6.89 & 59 \\
\hline 17 & HD 2733 & $52.71 \quad(46.33)$ & 0.34 & 93 & 96 & 9.16 & 7.55 & 67 \\
\hline 18 & HD 2851 & $48.18 \quad(43.75)$ & 0.38 & 90 & 88 & 8.15 & 7.83 & 62 \\
\hline 19 & HD 2932 & $54.98 \quad(47.63)$ & 0.32 & 90 & 94 & 8.75 & 8.24 & 70 \\
\hline 20 & HD 2967 & $49.31 \quad(44.4)$ & 0.39 & 88 & 89 & 8.4 & 7.79 & 64 \\
\hline 21 & HD 3043 & 50.19 & 0.36 & 90 & 94 & 8.91 & 7.46 & 64 \\
\hline 22 & DBW 17 & $45.58 \quad(42.27)$ & 0.43 & 86 & 95 & 8.48 & 7.08 & 58 \\
\hline 23 & RAJ 3765 & $56.11 \quad(48.28)$ & 0.32 & 90 & 95 & 9.19 & 7.92 & 71 \\
\hline 24 & DPW 621-50 & $45.71 \quad(42.35)$ & 0.43 & 89 & 90 & 8.88 & 7.15 & 59 \\
\hline 25 & KRL 19 & $54.98 \quad(47.63)$ & 0.32 & 93 & 90 & 8.44 & 8.48 & 70 \\
\hline 26 & C 306 & $41.48 \quad(39.92)$ & 0.45 & 86 & 83 & 6.72 & 8.03 & 59 \\
\hline 27 & K 307 & $52.71 \quad(46.33)$ & 0.39 & 93 & 92 & 7.01 & 8.48 & 66 \\
\hline \multirow[t]{4}{*}{28} & DPW71 & $39.04 \quad(38.5)$ & 0.48 & 93 & 88 & 6.93 & 8.03 & 55 \\
\hline & Mean & 50.86 & 0.37 & 90.33 & 93 & 8.57 & 7.85 & 65 \\
\hline & Range & $\begin{array}{l}39.04- \\
57.11\end{array}$ & $\begin{array}{l}0.32- \\
480\end{array}$ & $\begin{array}{l}85- \\
95\end{array}$ & $\begin{array}{l}83- \\
98\end{array}$ & $\begin{array}{l}6.72- \\
9.44\end{array}$ & $\begin{array}{l}6.89- \\
8.84\end{array}$ & $\begin{array}{l}55- \\
72\end{array}$ \\
\hline & CD (at 5\%) & 1.482 & 0.015 & 4 & 4 & 0.008 & 0.062 & 2.33 \\
\hline
\end{tabular}

AA- Accelerated ageing test, EC- Electrical conductivity, Tz- Tetrazolium test,, pH- pH exudates test, SEI- Seedling emergence index, MET- Mean emergence time,, SE- Seedling establishment. 
The standard germination among all the varieties ranged from 81-92 \% with overall mean value of $88 \%$. The variety DBW 71 recorded maximum seedling length $(26.3 \mathrm{~cm})$ followed by C $306(25.3 \mathrm{~cm})$, whereas the variety PBW 590 showed minimum seedling length $(19.2 \mathrm{~cm})$. The seedling dry weight recorded maximum in the variety PBW 550 (169.33mg) whereas the variety PBW 590 showed minimum seedling dry weight (102.67mg). The seedling dry weight ranged from 102.67-169.33 with overall mean value (465.06 mg).

For Seed Vigour Index-1out of the 28 varieties, 15 varieties have higher mean values than overall mean value (1978) and remaining 13 varieties observed lower mean values than overall mean value. The variety DBW 71 recorded maximum value (2371) while the variety PBW 590 showed minimum value (1537). Seed vigour index-II data revealed that the variety PBW 550 showed maximum vigour index value of 15245 , whereas, PBW 590 recorded minimum value of 8216. Vigour Index-II ranged from 821615245 in all the varieties with average mean value of 12538. In accelerated aging test Variety WH 711 recorded maximum value $(57.11 \%)$ followed by WH $542(56.40 \%)$, whereas, the variety DBW 71 recorded minimum value $(38.78 \%)$.

In electrical conductivity test variety $\mathrm{HD}$ 2932 recorded minimum value (0.320), while variety DBW 71 showed maximum value (0.480). The maximum reading value means variety is poor for storage purpose and lower value means variety has good storability and process of aging in seed is low.

Tetrazolium test is a test for viability and correlated with germination \%. Varieties WH 542, PBW 509 and PBW 550 recorded maximum (95\%).For $\mathrm{Tz}$, whereas varieties WH 1138 and PBW 590 recorded minimum value (85. $\mathrm{pH}$ exudates is also used for testing of viability and correlated with the standard germination and Tetrazolium test. The varieties WH 711, WH 1124 and PBW 550 recorded maximum $\mathrm{pH}$ exudates (98\%), whereas, the variety $\mathrm{C} 306$ showed minimum $\mathrm{pH}$ exudates $(83 \%)$.

Seedling emergence index was observed in field condition and highest value was recorded in variety WH 1025 (9.94) and lowest value (6.72) was observed in variety C306.The seedling emergence index ranged from $6.72-9.94$ in all the varieties with average mean value of 8.57 . For mean emergence time, the variety PBW 590 took minimum time (6.89) days) for emergence, while variety WH 542 and WH 730 took maximum time (8.84 days) for emergence. The seedling establishment ranged from 55 $72 \%$ in all the varieties with average mean value of $65 \%$. The variety $\mathrm{WH} 711$ recorded highest seedling establishment $(72 \%)$, while the variety DBW 71 recorded lowest seedling emergence $(55 \%)$.

In conclusion, among all 28 varieties, K 307, Raj 3765, HD 2733, PBW 550, PBW 509, WH 1063, WH 1025, WH 730 and WH 711 showed superiority for almost all viability and vigour Parameters. Some tests like standard germination, accelerated ageing test, tetrazolium test and electrical conductivity were found most suitable methods for the prediction of vigour and seedling establishment of varieties under field conditions. Some varieties like C 306, PBW 590 and PBW 373 showed poor performance for all most all viability and vigour parameters

Whereas, variety DPW 71 showed very good performance for vigour parameters while it showed average performance for viability parameters. 


\section{References}

Abdul- Baki, A.A. and Anderson, J.D. 1973. In: Physiological and biochemical deterioration of seeds. Kozlowski, T.T. (ed.). Seed biology. 2: 283-315. Academic Press, New York.

Bishnoi,U.R. and Deloucne, J.C. 1980. Relationship of vigour tests and seed lots cotton seedling establishment. Seed Science Tech. 8:341-345

Black, M. and Beweley, J. D. 2000. Seed Technology and its Biological Basis. Sheffield Academic press Ltd, sheffield.

LIAO, M.; PALTA, J.A.; FILLERY, I.R.P. Root characteristics of vigorous wheat improve early nitrogen uptake. Australian Journal of Agricultural Research, Canberra, v.57, p.10971107, set. 2006.

Maguire, J. D. 1962. Speed of germination Aid in selection and evolution for seedling emergence and vigour. Crop Science, 2, 176-177.

Panse, V. G. and Sukhatme, P. V. 1967. Statistical methods for agricultural workers. Pp. 381. ICAR, New Delhi

Presley, J. T. 1958. Relations of protoplant permeability to cotton seed viability and predisposition to seedling disease. Plant Disease Reporter, 42: 85.

MEROTTO JÚNIOR, A. et al., A desuniformidade de emergência reduz o rendimento de grãos de milho. Ciência Rural, Santa Maria, v.29, n.4, p.595-601, 1999.

SLOANE, D.H.G.; GILL， G.S.; MCDONALD, G.K. The impact of agronomic manipulation of early vigour in wheat on growth and yield in South Australia. Australian Journal of Agricultural Research, Canberra,v.55, p.645-654, jul. 2004

Trawatha, S. E., Tekrony, D. M. and Hidebrand, D. F., 1995. Relationship of soybean seed quality to fatty acid and $\mathrm{C}_{6^{-}}$aldehyde levels during storage. Crop Science, 35: 141-142

TEKRONY, D.M.; EGLI, D. B. Relationship of seed vigor to crop yield: a review. Crop Science, Madison, v.31, p.816822, mai. 1991.

UN FAO (FAOSTAT) 2016. "World food situation: FAO cereal supply and demand brief". Rome, Italy: United Nations, FAO 8 December 2016.

UN FAO Division (FAOSTAT). 2014. Archived from the original on 6 September 2015.

\section{How to cite this article:}

Vikash Kumar, R.C. Poonia and Kautilya Chaudhary. 2018. Assessment of the Seed Vigour Potential in Different Varieties of Wheat. Int.J.Curr.Microbiol.App.Sci. 7(07): 354-361. doi: https://doi.org/10.20546/ijcmas.2018.707.043 